\title{
Research Paper Does food inflation make difference in consumption pattern? An experience from rural Assam, India
}

\section{Rakesh Kota and Nivedita Deka}

See end of the paper for authors' affiliations

Correspondence to :

\section{Nivedita Deka}

Department of Agricultural

Economics, Faculty of

Agriculture Assam

Agricultural University,

Jorhat (Assam) India

Email: ndeka1@rediffmail. com

Paper History :

Received : 20.06.2020;

Revised : 21.07.2020;

Accepted : 22.08 .2020
ABSTRACT : The study on food inflation and changing consumption pattern in Assam was conducted in Jorhat district of Assam during 2018. Data analysis from a random sample of 70 respondents showed that the consumption of rice, wheat, cooking oil, tea and eggs had increased while the consumption of lentil, sugar, milk, vegetables, fish and meat had decreased during 2016-17 over 201314. The decrease in consumption was mainly due to food inflation during the period. However, as rice is the staple for the people of the state, despite of increase in price, there was no decrease in consumption. Due to decline in price of cooking oil, it was found to be consumed more. Further, increase in overall income during 2016-17 over 2013-14 helped the respondents to consume more eggs and tea. Except meat, for most of the food items, the respondents of the study area consumed comparatively less amount than the recommended dietary allowance. Marginal households were more affected by food inflation in comparison to small and medium households. Increasing supply of food items through public distribution system in subsidized rate would help in combating the food inflation in long run.

KEY WORDS : Food, Inflation, Consumption, Rural

How To Cite This PAper: Kota, Rakesh and Deka, Nivedita (2020). Does food inflation make difference in consumption pattern? An experience from rural Assam, India. Internat. Res. J. Agric. Eco. \& Stat., 11 (2) : 226232, DOI : 10.15740/HAS/IRJAES/11.2/226-232. Copyright@2020:Hind Agri-Horticultural Society. 